\title{
MENTAL HEALTH OF INCARCERATED WOMEN IN THE STATE OF RIO DE JANEIRO
}

\author{
Márcia Vieira dos Santos ${ }^{1}$, Valdecyr Herdy Alves², Audrey Vidal Pereira ${ }^{3}$, Diego Pereira \\ Rodrigues ${ }^{4}$, Giovanna Rosário Soanno Marchiori ${ }^{5}$, Juliana Vidal Vieira Guerra ${ }^{6}$
}

${ }^{1}$ M.Sc. in Maternal-Infant Health. Nurse, State Penitentiary Administration Secretariat. Rio de Janeiro, Rio de Janeiro, Brazil. E-mail: enfa.marcia@oi.com.br

${ }^{2}$ Ph.D. in Nursing. Professor, Maternal-Infant and Psychiatry Department, Escola de Enfermagem Aurora de Afonso Costa (EEAAC), Universidade Federal Fluminense (UFF). Rio de Janeiro, Rio de Janeiro, Brazil. E-mail: herdyalves@yahoo.com.br

${ }^{3}$ Ph.D. in Public Health. Professor, Maternal-Infant and Psychiatry Department, EEAAC, UFF. Rio de Janeiro, Rio de Janeiro, Brazil. E-mail: auviprof@yahoo.com.br

${ }^{4}$ M.Sc. in Nursing. Member of the Research Group Maternity, Women and Children's Health of the EEAAC, UFF. Rio de Janeiro, Rio de Janeiro, Brazil. E-mail: diego.pereira.rodrigues@gmail.com

${ }^{5}$ M.Sc. in Maternal-Infant Health. Professor, Faculdade Novo Milênio. Vitória, Espírito Santo, Brazil. E-mail: giovannasoanno@gmail.com

${ }^{6}$ Master's student in Maternal-Infant Health, UFF. Nutritionist, São João da Barra Municipality. São João da Barra, Rio de Janeiro, Brazil. E-mail: julianavvguerra@yahoo.com.br

\section{ABSTRACT}

Objective: identifying the factors related to the mental health of women in a prison in the Statey of Rio de Janeiro.

Method: a descriptive, exploratory and qualitative study conducted between October 2014 and January 2015 in a female prison in the State of Rio de Janeiro. Forty (40) incarcerated women were interviewed. The information collected was discussed based on content analysis, using a thematic based modality.

Results: the following factors that affect the mental health of incarcerated women have been identified: anxiety, stress, depression, altered sleep patterns, misuse of psychotropic medication, sexual abstinence, and interruption of family relationships, in addition to the precarious conditions of confinement.

Conclusion: we emphasize the need for a multiprofessional team in mental health within the prison system that meets the needs of this population, ensuring applicability of the National Policy of Comprehensive Healthcare for Persons Deprived of Freedom, reinforcing dialogue with Humanization Policies and Health Promotion, with the intention of performing healthcare that contributes to comprehensive healthcare for incarcerated women.

DESCRIPTORS: Women's health. Prisons. Integrality in Health. Mental health. Health promotion.

\section{SAÚDE MENTAL DE MULHERES ENCARCERADAS EM UM PRESÍDIO DO ESTADO DO RIO DE JANEIRO}

\section{RESUMO}

Objetivo: identificar os fatores relacionados à saúde mental de mulheres em um presídio do Estado do Rio de Janeiro.

Método: estudo descritivo, exploratório, qualitativo, realizado entre outubro de 2014 e janeiro de 2015 numa penitenciária feminina do Estado do Rio de Janeiro. Foram entrevistadas 40 mulheres privadas de liberdade. As informações coletadas foram discutidas com base na análise de conteúdo, modalidade temática.

Resultados: foram identificados os seguintes fatores que afetam a saúde mental das mulheres privadas de liberdade: ansiedade, estresse, depressão, alteração do padrão de sono, uso indevido de medicação psicotrópica, abstinência sexual, interrupção das relações familiares, além das precárias condições de confinamento.

Conclusão: destaca-se a necessidade de haver uma equipe multiprofissional em saúde mental dentro do sistema prisional que atenda as necessidades dessa população, e assegurando a aplicabilidade da Política Nacional de Atenção Integral à Saúde no Sistema Prisional, reforçando o diálogo com as Políticas de Humanização e Promoção da Saúde, com vistas à realização de cuidados que contribuam para a atenção integral da saúde das mulheres encarceradas.

DESCRITORES: Saúde da mulher. Prisões. Integralidade em saúde. Saúde mental. Promoção da saúde. 


\section{SALUD MENTAL DE LAS MUJERES EN UNA PRISIÓN EN EL ESTADO DE RÍO DE JANEIRO}

\section{RESUMEN}

Objetivo: identificar los factores relacionados con la salud mental de las mujeres en una prisión en el estado de Río de Janeiro.

Método: estudio cualitativo exploratorio, descriptivo, realizado entre octubre de 2014 y enero de 2015 en una cárcel de mujeres en el estado de Río de Janeiro. Cuarenta mujeres privadas de libertad fueron entrevistados. La información recogida se discutió sobre la base de análisis de contenido, modalidad temática.

Resultados: se identificaron los siguientes factores que afectan a la salud mental de las mujeres privadas de libertad: ansiedad, estrés, depresión, trastornos del sueño patrón, el mal uso de la medicación psicotrópica, abstinencia sexual, la interrupción de las relaciones familiares, además de las condiciones de confinamento.

Conclusión: el estudio pone de relieve la necesidad de un equipo multidisciplinario de salud mental dentro del sistema penitenciario que cumpla con las necesidades de esta población, y garantizar la aplicabilidad de la política de Atención Integral Nacional de Atención de la salud en las prisiones, el fortalecimiento del diálogo con la política de Humanización y la promoción de la salud, con miras a la celebración de la atención que contribuyen a la atención integral de la salud de las mujeres privadas de libertad.

DESCRIPTORES: Salud de la Mujer. Prisiones. Integralidad en Salud. Salud mental. promoción de la salud

\section{INTRODUCTION}

At the end of the eighteenth century and the beginning of the nineteenth century, "explicit public punishments" were replaced by confinement in institutions, based on the deprivation of freedom. In this period, imprisonment appears as the most immediate and civilized form among all penalties, with the function of being a last resort disciplinary method. Through its regulatory action, a series of powers is developed over the life of the person deprived of their freedom, recognized by society as a space used for punishing individuals who have committed a certain type of violation, and at the same time, for protecting society. It is an institution that must preserve the dignity of the human being, since its objective is to make the conditions feasible so that when this individual returns to freedom they can live in society. However, prisons have not been able to perform this function of reintegrating those (who were once) deprived of freedom..$^{1-2}$

In prison, the confinement conditions are determinant for the health-disease process and for the relationship between (health) problems and health needs of those deprived of freedom, since numerous health disorders can arise given the precariousness of the prison system, in addition to preexisting ones, thus aggravating the conditions and causing greater losses to the ways of life of that person. ${ }^{3}$ Therefore, the overpopulation that exists in several prisons in the world generates mental health problems in prisoners, in addition to behavioral disorders due to anxiety that leads to self-mutilation from incisional injuries, ingestion of foreign objects and even suicide. ${ }^{4}$
Currently in Brazil, the prison system coexists within a disturbing picture regarding health. An increase in the incarcerated population living in precarious conditions makes the environment unhealthy, at high risk and favorable to the proliferation of diseases ${ }^{5}$ such as tuberculosis and sexually transmitted diseases. ${ }^{6}$ Moreover, because they are institutionalized, the majority of the prison population becomes physically and mentally more susceptible to illness, especially chronic suffering, thereby generating physical and psychological discomfort. ${ }^{7}$

The need to observe the human being from a comprehensive point of view makes it difficult to separate physical health from psychological or mental health. For example, the complex relationship involving issues that transit between what is observed and/or expected of statistical averages and frequencies, and what is possible or chosen amid the contradictions of everyday reality, ${ }^{8}$ influencing the potentiality of risk factors which affect health.

With regard to the female population, factors that affect health or aggravations of previous situations overlap, not only due to the precariousness of the current conditions of Brazilian prisons, ${ }^{9}$ but also by the presence of factors related to the institutional environment and sexual issues. Incarcerated women are more vulnerable to illness compared to men deprived of their freedom. ${ }^{10-11}$ In addition to the biological aspects, there are also characteristics related to the female being, such as sensitivity, emotion, sadness, and anguish, among other feelings, ${ }^{12}$ stressing agents that contribute to the mental health impairment of this population. ${ }^{7}$ 
When we reflect on the issue of mental health, we reach the understanding that it is something complex, not only involving the absence of mental disturbance, but also biological, psychological and social factors that directly interfere (with it). ${ }^{13}$ Thus, employment, education, poverty, housing, social discrimination, gender violence, family environment, social exclusion, stigma, cultural concepts about community mental illness and stressful life events are social and economic determinants that directly interfere with mental health. ${ }^{13}$

In this perspective, mental health within the prison system is a public health and safety problem. In the case of women, it has been proven that there is a higher prevalence of illness than occurs in women not subjected to freedom deprivation, demonstrating the need for the prison system to ensure comprehensive and interdisciplinary care. ${ }^{14}$

Based on the above, this study aimed to identify the factors related to the mental health of women in a prison in the State of Rio de Janeiro.

\section{METHOD}

This is a descriptive, exploratory research implementing a qualitative approach. It was performed in the period from October 2014 to January 2015, in a female prison located in the State of Rio de Janeiro.

Study participants were 45 incarcerated women in a female prison in the metropolitan region I of the State of Rio de Janeiro. Their inclusion occurred through a simple random selection process, using an official nominal list of the prisoners, which included all those who had medical records in the existing health service in the prison. Exclusion criteria considered refusal or those women who gained their freedom, those who were suspended for security reasons, and those who were transferred to another prison unit. Thus, of the 45 women who were part of the study, five were excluded for the following reasons: one was released, two were suspended for security reasons, one refused (to participate), and one was transferred to another prison unit, thus totaling 40 prisoners participating in the study.

The prison under study has a health clinic to specifically serve incarcerated women. The entrance to this clinic is guarded by a barred door with pad- lock, which is locked when no health professionals are present. There is a room in this sector for dental service, a room for attending to pregnant women with their respective medical records, rooms for individual care, a pharmacy/storeroom, bathrooms for employees and for the prisoners, and a space where the medical records of all prisoners are kept. The clinic has a health team consisting of doctors, nurses, nursing technicians and dentists. The psychology and social services do not attend at the health clinic, as they have rooms in another sector.

Data collection was performed from the medical records and with a semi-structured interview applied by the main investigator, which took place in the prison's health clinic. At the beginning of the interview, the researcher presented the research objective and guaranteed anonymity of the interviewees/subjects. These women verbally expressed their willingness to be part of the study and on the day of the interview they were authorized by the penitentiary agents who were on duty. Participants voluntarily answered a script with open and closed questions.

It is worth pointing out that in order to be allowed to perform the research in the prison system, the Penitentiary Administration Department of the State of Rio de Janeiro required compliance with certain conditions for data collection, such as: entry into the prison could only take place after daily conference with the inmates had been held; the exit would have to be held one hour before the night count; audio and video recordings, photographs and reproduction of any document inside the prison is prohibited; and signing of the Free and Informed Consent Form was also not allowed, since the Rio de Janeiro Penitentiary Administration Secretariat does not authorize provision of nominal information identification of the inmates. In this case, the Institution on behalf of the State is the responsible organ for authorizing and taking responsibility for the participation of prisoners in activities involving research.

Thus, at the time of the interview, the researcher had to transcribe the answers to the questions and read the transcripts so that the interviewees could hear and demonstrate agreement or disagreement with the researcher's writing, seeking to ensure maximum accuracy in the data collection of the participants' responses. 
In order to perform data collection analysis, we opted for using thematic content analysis, since we hoped to obtain information that expresses approximation with the reality narrated by the participants. Conducting focus groups of the interviews in this study enabled elaboration of the thematic unit "Social determinants that interfere in the conditions of incarcerated women" and the thematic category "Mental health as a product of the life conditions of imprisoned women". Testimony analysis was based on an updated theoretical framework on this theme.

The research was approved by the Ethics and Research Committee of the Universidade Federal Fluminense (UFF), under protocol number 696.795/ 2014 and CAAE number 27061114.3.0000.5243, and authorized by the Penitentiary Administration Secretary of Rio de Janeiro, through process E-2108753/2014, in compliance with Resolution number 466/2012 of the National Health Council, which refers to research involving human beings. In order to guarantee secrecy and anonymity of the interviewees, their statements are identified by alphanumeric codes (W1,..., W40).

\section{RESULTS}

The thematic unit "Social determinants that interfere in the conditions of incarcerated women" made it possible to observe that several factors interfere with the mental health of women deprived of their freedom. Prior to the incarceration period, information regarding family history of psychiatric illness and dependence on alcohol and illicit drug use appeared in the interviews. Moreover, the situation of physical, sexual and psychological violence was highlighted. During institutionalization inmates indicated experiencing: pain, sadness, loneliness, abandonment, revolt, anxiety, stress, depression, alteration of temporal perception and sleeping pattern, use of psychotropic medication, interruption of family relationships, and sexual abstinence, in addition to the precarious confinement conditions.

\section{Mental health as a product of the incarcerated woman's living conditions}

From the outset, it was observed that the factors that affected the mental health of incarcerated women were directly related to their family his- tory of psychiatric illness and to the current health condition of their everyday life in the prison. This relationship can be noticed from the following statements: [...] when I was little, I did not get along with my father. [...] my mother took me to the mental health service. [...] I used to hurt myself [...] and I continued to do so [...] I went into a very deep depression [...] (W4); [...] my aunt was admitted into the psychiatric hospital. [...] and this messes with my head [...] (W13); [...] it got worse in prison. [...] I got more aggressive, I have visions of the dead. I feel like I'm not normal [...] (W26).

In relation to pre-incarceration factors, alcohol and illicit drug dependence appeared in the interviews, influencing mental health during the period of freedom deprivation.

Alcohol consumption before prison was confirmed by 21 respondents, while 25 reported using illicit drugs, of which 15 reported only consuming one type of drug, three consumed two types of drugs and six consumed three or more types of drugs. In relation to they had crime committed which led to their arrest, 27 said they were arrested for drug trafficking, six for theft, three for larceny, two for homicide, one for torture of a minor and one did not answer.

An important question identified in the testimonies concerns the situation of physical, sexual and psychological violence suffered before and during the time of arrest. Prior to incarceration, 24 women responded that they suffered some type of violence, while 16 did not express it in their speech or did not perceive an occurrence of situations that characterized violence. Among the 24 who suffered violence, ten reported only one type, with emphasis on physical violence, and 14 reported more than two types. Of these 24 women, 20 identified the perpetrator as a relative, and four as unknown persons.

Regarding the situations of violence experienced in prison, some women reported that the possibilities of dealing with episodes related to both physical and psychological violence during the sentence period are numerous. We may observe in the following testimonies how the presence and relation to situations of violence are exhausting and frightening: [...] lots of screaming and fighting all day. [...] it makes me afraid. [...] of being by myself [...] (W30); [...] I'm disturbed. [...] I sometimes speak to myself $[\ldots]$ (W18). 
In general, during the period when these women were institutionalized the intense presence of feelings related to sadness, pain, loneliness, abandonment, revolt and anxiety were pointed out in their testimonies. These emotions, exemplified in the following reports, are stressors that contribute to the mental health impairment of this population: [...] I feel suffocated [...] but incarcerated [...] (W25); [...] I feel anxiety and worry $[\ldots]$ (W4); [...] I'm trying to keep focused/stable, but I'm very afraid [...] (W36).

It can be deduced that mental health was more affected than physical health. Even in facing the difficulty of realizing dual positions considering the totality of people's lives, some testimonies point to the gravity that surrounds possible dissociations, which are related to the psychological aspects and suffering.

[...] no physical problems [...] only mental problems, $[\ldots]$ depression $[\ldots]$ (W12).

\section{[...] I really need a psychiatrist [...] (W7).}

Due to confinement, women have a dimension of conflicts that trigger a series of related situations which adversely affect health and life conditions in an overlapping and multifactorial way. The participants clearly stated that they were in a period of great stress. Their reports show situations that characterize states of depression and suicidal ideation, according to the following statements: [...] I find myself alone in time. [...] I feel the depression of abandonment. [...] sometimes I feel like I'm terrible. [...] I want to die, [...] to stop suffering [...] (W3); [...] stressed [...] I take out my problems on the police [...] [Penitentiary agents] (W16).

The use of psychotropic medication is also presented as an issue that adds to the previous ones, demonstrating encumbering correlations. In many situations, it appears in speeches as an abusive and disorderly habit, which may occur on its own. Thus, the use of controlled medication (not always under medical supervision) meets their personal demands and needs, according to the statements: [...] to stay calm. [...] I get high [...] (W4); [...] I only take psychotropic medication when necessary [...] to sleep [...]. If I've never used drugs, why should I get high on drugs? It is a chemical dependency [...] (W8); [...] because the medication makes me calmer [...] I'd rather sleep [...]. This medicine makes me sleep. [...] it is too stressful here [...] (W10); [...] I need the medicine to calm down. [...] (W36).
In certain situations, the use of psychotropic medication has other intentions, such as disconnecting from the world. It can be inferred that inducing sleep for some women through the use of medication reflects a way of escaping and/or adapting to the harsh reality, according to their statements: [...] controlled medication to shut me down ... time passes faster [...]. I don't see anything bad happening to the people I like [...] (W5); [...] I want to sleep and just wake up when I leave [...] (W13); [...] it's better to sleep than to stay awake [...] (W17).

However, it has become clear that the use of psychotropic medications most of the time is related to the need to maintain a sleeping pattern and to minimize existing conflicts in daily prison life. In a related way to the dependent use of psychotropic medication and the need to maintain sleep, there are issues regarding the environment, which hinder prison life and affect mental health. This is exemplified by the position of respondent 2, who ironically states: [...] sleeping in jail? This is the place where you sleep the least [...] (W2).

[...] lots of anxiety. I wake up at $4 o^{\prime}$ clock. [...] I feel anxious and worried [...] (W4).

[...] I saw a death that shook me [...] My nervous system was shaken up [...] (W14).

[...] waking up here is crazy. [...] it's a hospice here [...] (W18).

This institutionalized environment interferes with the mental health conditions of many imprisoned women due to factors that can be identified from their speeches: [...] the noises of the inmates bother me [...] the yelling and the fuss [...] (W1); [...] the agitation disturbs me [...] because of our problems and those of the women who live with us [...] (W7); [...] here is a place that no vulture deserves to be. [...] I see and hear a lot. Silence is the most important [...] (W9).

The noise and agitation identified in these testimonies highlight the difficulty of the participants to conciliate sleep: [...] lack of respect for the human being [...] (W19); [...] interrupted sleep [...] I sit, I take medicine, I rock myself [...]. I wake up [...] I sleep during the day and stay up at night [...] (W24).

This sleep disorder may also occur contradictorily from hypersomnia, which is characterized by excessive drowsiness, and may be present during the day. It may also cause prolonged sleep during 
the night time period. This disorder may frequently occur during incarceration time, as seen in statements that they report sleeping at all times, and have long, persistent sleep. However, the difficult conditions of the prison environment aggravated by constant noise alter the sleeping pattern of incarcerated women. To a certain extent, it can be inferred that this excessive sleep is tied to a way of escaping from the difficult reality in the daily life of the prison, as in the case exemplified below: [...] I sleep too much in jail [...] not even the noise of the prison bothers me [...] (W11).

The situations that characterize the institutionalized environment of the prison constitutes an idle space that also contributes to the interference of the temporal notion, leading the interviewees to say that they were talking with the Divine Spirit (God) and reflecting on life.

It can be inferred that institutionalized time can be characterized by the predominance of unemployment. Thus, idleness is another factor that interferes with the mental health conditions of incarcerated women. These testimonies illustrate this point: [...] there's not much choice here, I keep it to myself [...]. God and I [...]. I don't usually mix with others. [...] (W1); [...] I stare at the time. [...] talk to God [...] (W9); [...] thinking about life, talking to God [...] (W10); [...] here you lose track of the world outside [...] (W39).

Another factor that negatively interferes with mental health conditions concerns sexual life during the incarceration period. This issue was identified through the frequency of intimate visits and the related inference of sexual abstinence. Of the total of 40 participants, 34 said they did not have intimate visits, three had and three were in the process of trying. Of the three who had intimate visits, they all go to another prison where their partners are imprisoned.

In the midst of so many conflicting situations arising from incarceration, the interruption of family relationships appears in the testimonies as something concerning for women: [...] my family could come and visit me. [...] (W3); [...] my mental health is terrible. I have no visitors or letters [...] (W9); [...] I cry, I cry a lot [...] I miss them [...] I think a person should not have to go through this in their life. [...] (W19).

Among the many concerns, women deprived of their freedom mention their children: [...] I'm miserable that I cannot see my daughter. [...] (W5); [...] I worry. [...] I think about my children [...] (W20).

This concern expresses a direct relation with mental health as the testimonies that report suffering, sadness and disturbance are found.

[...] I miss my family [...]. I sleep with medication [...] (W27).

[...] I keep thinking about the family, even more about my children. [...] (W34).

[...] it is not good, mentally it isn't $t$...] The distance and the longing for my kids, I am troubled [...]. It is the first time that I have been separated from my children, [...] I did not leave them alone [...] (W35).

[...] sad, when I think of my kids [...] (W38).

In addition, in a contradictory way, it was possible to identify that incarceration can contribute to women reflecting about their life, according to their testimonies: [...] I've learned many things in here, I have renewed myself [...].Prison has taught me that hardearned money is little, but it goes a long way [...]. God put me in here to reflect, so that I could be a new woman outside [...] (W20); [...] I will pay for my mistakes [...] I'm going to take the prison time with balance [...] (W24).

\section{DISCUSSION}

The United States registers three times the amount of people with mental health problems in their prisons than in hospitals. In these penal institutions, the individual has the right to basic health care, which characterizes jails and prisons as sites of public health interventions. Thus, the need for the American justice and health system to be interlinked and to address social problems related to mental health is advocated. ${ }^{15}$

In the Brazilian prison system, mental health is also a matter of concern, especially for females who are five times more likely to present mental problems than women with freedom. ${ }^{15}$ This reality makes the mental health of the population a topic that should be better understood and researched.

In this study on mental health during the confinement period, women reported: anxiety, stress, depression, alteration of sleeping pattern, misuse of psychotropic medication, abusive use of licit and illicit drugs, sexual abstinence, poor confinement conditions and interruption of family relationships. Most had already suffered some form of violence. 
Thus, the relationship between the mental health of the interviewees and their previous histories revealed signs of cohabitation with some psychiatric component and/or existence of a family person with a psychiatric history. To avoid worsening the depressive symptoms that appear in the period of incarceration, external support and the support of a mental health service are important, as confirmed by some studies. ${ }^{10,13,16}$

In this study, most interviewees reported that their arrest was due to drug trafficking. Most of them had already had involvement with licit and illicit drugs prior to arrest and were using these substances when in freedom (before being arrested). This history of abusive use of alcohol and other drugs is not uncommon in detained women, ${ }^{17}$ and may be associated with the perpetuation of violence and criminality. ${ }^{13}$ It is estimated that most inmates have a direct relationship with drugs, which may contribute to a possible increase in committed crimes. ${ }^{13}$ The gender comparison shows that the proportion of women incarcerated with a dependence on alcohol or drugs is higher than that of men deprived of their freedom. ${ }^{16}$

In general, these women are more vulnerable; they appear in criminal statistics sometimes as victims or as perpetrators of violence. ${ }^{18} \mathrm{~A}$ study finds that $60 \%$ of incarcerated women have already suffered some kind of violence (physical, sexual or psychological) during their lifetime. ${ }^{19}$ Regarding the type of violence, one study shows that due to their socio-demographic profile (low schooling, less favored economic conditions, low qualification occupations), these women suffer more physical and sexual violence. ${ }^{20}$ Similar to this study, reports from an American study estimate that $43-57 \%$ of incarcerated women were victims of physical or sexual abuse prior to incarceration.

Prison is recognized as a space that can have serious psychological implications on the lives of women who have far higher rates of mental health problems than male prisoners and the community at large. ${ }^{10}$ As observed in this study, the presence of several feelings that trigger stress may contribute to impairing the mental health of individuals living there.

The environment is an important social determinant in the context of mental health. In the case of the penitentiary environment, it disrupts the emotional state of persons deprived of freedom and contributes to their momentary or permanent mental imbalance. ${ }^{12}$ This happens because abrupt changes that catalyze stressors intensify feelings of anxiety, fear, helplessness, isolation, rejection, impotence, and decreased self-esteem. ${ }^{21}$

The institutionalized environment shakes relationships, frightening and provoking the isolation. Incarcerated women coexist daily with tensions and conflicts that can be developed by precarious confinement conditions, triggering the presence of factors that affect their mental health. ${ }^{7}$ Such emotional changes may interfere with the biological, resulting in psychological illness. ${ }^{9}$ In this study, emphasis was placed on the presence of situations related to stress and characteristics related to depression symptomatology. However, depression symptoms tend to be naturalized in the face of daily stress in incarceration. They become psychopathological when they present disproportionate reactions to the causative event and persist for a considerable period of time. ${ }^{21}$

A study that sought to understand the meanings of incarceration and coping strategies from the perspective of multifactorial analysis allowed us to infer that the mental health of women in the context of incarceration was more affected than physical health. Thus, it was understood that incarcerated women need specialized care, especially regarding mental health service, to ensure the preservation of their health during their imprisonment period. ${ }^{7}$

Another situation related to the context of prison reality appeared in the interviews conducted for this study which signaled interference in mental health conditions, namely that many women reported changes in their sleeping patterns. It is known that in daily life, sleep interferes with mood, memory, attention, sensory registering and reasoning; therefore, changes in sleep determine a poor quality of life and interfere with health, sometimes in a very severe way. ${ }^{22}$ However, insomnia is not the only event associated with the onset of negative factors linked to mental health. Approximately $10 \%$ to $20 \%$ of depressed patients may report excessive sleep (hypersomnia) in the form of prolonged nocturnal sleep episodes and increased daytime sleeping/drowsiness. ${ }^{23}$ Thus, sleep disorders (insomnia and hypersomnia) should be recognized in order to allow preventive care and early treatment. ${ }^{22}$ 
Linked to the need to regularize sleeping patterns, the need to escape from daily prison reality and to minimize depression symptoms, many prisoners take psychiatric medication. Among women, one of the factors that significantly increases depression symptomatology is the use of psychiatric medication without prescription during imprisonment, ${ }^{10}$ understanding that self-medication of such substances is responsible for the increased rate of mental illness comorbidities. ${ }^{24}$

The use of controlled medication could be adequately monitored if the mental health team was present in the daily life of the prison. Thus, they could identify factors that affect health and the needs related to preventing uncontrolled consumption of these medications and be able to work towards promoting health. However, a study reveals that mental health programs are insufficient to meet the specific or comprehensive healthcare needs of women, especially those incarcerated in prisons. ${ }^{16}$

In line with the results of a study on the health of incarcerated women, ${ }^{23}$ in this study it was also possible to observe that the incarceration conditions and deprivation of relationships in society may affect the inmates' chronological perception of daily time, especially when idle time is equivalently greater than occupied and measured time.

In addition to the precarious confinement conditions and this relationship with time, it was also possible to identify factors associated with the sexual lives of women during incarceration. Most of the interviewees reported sexual abstinence. It is worth mentioning that an intimate visit stimulates affectionate and family bonds, being fundamental in reintegrating this woman to the family, with the collaboration of their partner at that time becoming essential for strengthening their self-esteem in the imprisonment period, as pointed out by the study on the penal system and gender. ${ }^{25}$

However, there is difficulty in enabling this right guaranteed by Resolution N. 4 of 29 June 2001, which recommends that the State Penitentiary Departments or similar bodies assure/guarantee the right of intimate visits to prisoners residing in prison institutions.

In this study, the few interviewees who had an intimate visit were assured that they would travel to the male prisons where their partners were incarcer- ated. Also, it's worth noting that a study on the penal system and gender concluded that sexual abstinence and the difficulty in performing intimate visits are situations that, when imposed by the penal system, interfere in the mental health of these women. ${ }^{25}$

Another factor that triggers disturbances in women's mental health during incarceration is the disruption of family relationships ${ }^{9-10}$ and the significant weakening of bonds from previous relationships. After conviction, there is a breakdown of the family nucleus, a situation that also points to the inequality of the sexes, as it does not occur as often in relation to men when they are incarcerated..$^{18}$ Due to abandoning family members, friends and, above all, their children, the inmates experience feelings of sadness, pain, hopelessness and loneliness.?

Thus, deprivation of freedom and the consequent fracture of affective bonds have an impact on the mental health of these women, as waiting to regain contact with relatives is one of the ways of coping in prison. ${ }^{7}$ Contact with family and friends reinforces social bonds and is fundamental for reintegrating these women into society. ${ }^{25}$ Since the condition of being imprisoned is only temporary, the family must continue to be, for the prison population, a reference for life outside the walls. ${ }^{26}$

\section{CONCLUSION}

In this research it was possible to identify some factors from the interviewees' statements that affect the mental health of incarcerated women. It was observed that the conditions experienced in the prison environment contribute to provoke fear, anxiety, loneliness, anguish, sadness and revolt, feelings that trigger stress and depression. Other situations also affect mental health in the penitentiary environment, such as: misuse of controlled drugs, exposure to violence, disturbances to sleep, norms and coercive routines, idle time, lack of intimate visitation, and interruption of family ties, especially regarding their children.

The affective bond between mother-childcompanion-family must be preserved, contributing to reduce the abandonment of these women during their incarceration period. Thus, prisons need to encourage children and families of prisoners to attend the institution, given the possibility of procedural 
visits, thus contributing to an investment in the process of re-socialization.

As it is a specific group which is vulnerable, it is considered extremely important to work on improving healthcare networks and advancing specific public policies which ensure better health conditions for incarcerated women, especially with regard to mental healthcare since it is a population which more prone to psychological suffering as a result of the incarceration period.

The association between prison institution and psychiatric institution appeared frequently in the testimonies of the study participants. Women who attended the mental health service when they were released or reported having some mental distress during the confinement period required follow-up with a mental health team inserted in the prison system.

It is important to emphasize the need for a health team to constantly supervise the mental health service within the penitentiary or even a reference service within the mental health network in order to ensure care continuity for those incarcerated. Therefore, the complexity that surrounds the daily life of relationships in the prison system in facing the set of factors that directly affect mental health conditions can still elicit reflections on the part of women deprived of freedom, who, even when expressing guilty sentiments, may constitute learning about life itself.

\section{ACKNOWLEDGEMENTS}

The authors are grateful to the Carlos Chagas Filho Foundation for Research Support in the State of Rio de Janeiro (FAPERJ).

\section{REFERENCES}

1. Cunha EL. Ressocialização: o desafio da educação no sistema prisional feminino. Cad CEDES [Internet]. 2010 [cited 2015Jun 10];30(81):157-78. Available from: http:// www.scielo.br/pdf/ccedes/v30n81/a03v3081.pdf

2. Foucault M. Vigiar e punir: nascimento da prisão. Tradução Raque Ramalhete. 41ª ed. Petrópolis (RJ): Vozes; 2013.

3. Ministério da Saúde (BR) [Internet]. Plano Nacional de Saúde do Sistema Penitenciário. Brasília (DF): MS; 2005 [cited 2015 Jun 10]. Available from: http:/ / bvsms. saude.gov.br/bvs/publicacoes/cartilha_pnssp.pdf

4. García-Guerrero J, Marco A. Sobreocupación en los centros penitenciarios y su impacto en la salud. Rev Esp Sanid Penit [Internet]. 2012 [cited 2016 May 10]; 14(3):106-13 Available from: http://scielo.isciii.es/ pdf/sanipe/v14n3/en_06_revision2.pdf

5. Souza MCP, Alencar Neto FJ, Souza PCC, Silva CLC. Atenção à saúde no sistema penitenciário: revisão de literatura. Rev Interd [Internet]. 2013 [cited 2015 Jun 10]; 6(2):144-51. Available from: http:// revistainterdisciplinar.uninovafapi.edu.br/index. php/revinter/article/view/59/pdf_32

6. Souza KMJ, Villa TCS, Assolini FEP, Beraldo AA, França $\mathrm{UM}$, ProttiST, et al. Delay in the diagnosis of tuberculosis in prisons: the experience of incarcerated patients. Texto Contexto Enferm [Internet]. 2012 jan/mar [cited 2015 Jun 10]; 21(1):17-25. Available from: http:/ / www.scielo.br/ pdf/tce/v21n1/en_a02v21n1.pdf

7. Lima GMB, Pereira Neto AF, Amarante PDC, Dias MD, Ferreira Filha MO. Mulheres no cárcere: significados e práticas cotidianas de enfrentamento com ênfase na resiliência. Saúde Debate [Internet]. 2013 [cited 2015 Jun 10); 37(98):446-89. Available from: http:/ / www. scielo.br/pdf/sdeb/v37n98/a08v37n98.pdf

8. Gama CAP, Campos RTO, Ferrer AL. Saúde mental vulnerabilidade social: a direção do tratamento. Rev Latinoam Psicopatol Fundam [Internet]. 2014 [cited 2015 Jun 10]; 17(1):69-84. Available from: http:// www.scielo.br/pdf/rlpf/v17n1/v17n1a06.pdf

9. Neri MS, Oliveira JF, Nascimento ER, Gusmão MEN, Moreira VS. Presas pelas drogas: características de saúde de presidiárias em Salvador/Bahia. Rev Baiana Enferm [Internet]. 2012 [cited Jun 10]; 25(2):121-32. Available from: https://repositorio.ufba.br/ri/ bitstream/ri/6857/1/BB.pdf

10. Canazaro D, Argimon IIL. Características, sintomas depressivos e fatores associados em mulheres encarceradas no estado do Rio Grande do Sul, Brasil. Cad Saúde Pública [Internet]. 2010 [cited 2015 Jun 10]; 26(7):1323-33. Available from: http:/ / www.scielo.br/ pdf/csp/v26n7/11.pdf

11. Silva NC, Rosa MI, Amboni G, Mina F, Comim CM, Quevedo J. Transtornos psiquiátricos e fatores de risco em uma população carcerária. Arq Catarin Med [Internet]. 2011 [cited 2015 Jun 10]; 40(1):72-6. Available from: http://www.acm.org.br/revista/ pdf/artigos/850.pdf 
12. Santos MAM, Rodrigues GB. A ressocialização do preso no Brasil e suas consequências para a sociedade. E-civitas [Internet]. 2010 jul [cited 2015 Jun 10]; III(1):146. Available from: http://revistas.unibh.br/index. $\mathrm{php} / \mathrm{dcjpg} /$ article/view/64/39

13. Alves AAM, Rodrigues NFR. Determinantes sociais e econômicos da saúde mental. Rev Port Saúde Publica [Internet]. 2010 [cited 2015 Jun 10]; 28(2):12731. Available from: http:/ / www.scielo.mec.pt/pdf/ rpsp/v28n2/v28n2a03.pdf

14. Lopes RMF, Mello DC, Argimon IIL. Mulheres encarceradas e fatores associados a drogas e crimes. Ciênc Cognição [Internet]. 2010 [cited 2015 Jun 10]; 15(2):121-31. Available from: http:/ / www.cienciasecognicao.org/pdf/v15_2/11_121131_m308.pdf

15. Cloud D, Dougherty M, May RL, Parson J, Wormeli P, Rudman WJ. At the intersection of health and justice. Perspect Health Inf Manag [Internet]. 2014 Winter [cited 2016 May 10]; 11(Winter):1-4. Available from: http:/ / www.ncbi.nlm.nih.gov/pmc/articles/ PMC3995482/pdf/phim0011-0001c.pdf

16. Bergh BJVD, Gatherer A, Fraser A, Moller L. Imprisonment and women's health: concerns about gender sensitivity, human rights and public health. Genebra: World Health Organization; 2011 [cited 2015 Jun 10]. Available from: http:/ / www.who.int/ bulletin/volumes/89/9/10-082842/en/

17. Oliveira LV, Costa GMC, Medeiros KKAS, Cavalcanti AL. Epidemiological profile of female detainees in the Brazilian state of Paraíba: a descriptive study. Online Braz J Nurs [Internet]. 2013 [cited 2015 Jun 10]; 12(4):892-901. Available from: http://www. objnursing.uff.br/index.php/nursing/article/ view/4284

18. França MHO. Criminalidade e prisão feminina: uma análise da questão de gênero. Rev Ártemis [Internet]. 2014 [cited 2015 Jun 10]; XVIII(1):212-17. Available from: http:/ / periodicos.ufpb.br/ojs/index.php/ artemis/article/view/22547/12510
19. Agnolo CMD, Belentani LM, Jardim APS, Carvalho MDB, Pelloso SM. Perfil de mulheres privadas de liberdade no interior do Paraná. Rev Baiana Saúde Pública [Internet]. 2013 out/dez [cited 2015 Jun 10]; 37(4):820-34. Available from: http://files.bvs.br/ upload/S/0100-0233/2013/v37n4/a4480.pdf

20. Kramer K, Comfort M. Considerations in HIV prevention for women affected by the criminal justice system. Women's Health Issues [Internet]. 2011 nov [cited 2015 Jun 10]; 21(6 Suppl):S272-7. Available from: http://www.ncbi.nlm.nih.gov/pubmed/21782463

21. Tavares GP, Almeida RMM. Violência, dependência química e transtornos mentais em presidiários. Estud Psicol [Internet]. 2010 out-dez [cited 2015 Jun 10]; 27(4):545-52. Available from: http:/ / www.scielo.br/ pdf/estpsi/v27n4/12.pdf

22. Valle LELR, ValleELR, Reimão R. Sono eaprendizagem. Rev Psicopedag [Internet]. 2009 [cited 2015 Jun 10]; 26(80):286-90. Available from: http:/ / pepsic.bvsalud. org/pdf/psicoped/v26n80/v26n80a13.pdf

23. Santos MV. Saúde da mulher em uma penitenciária do Estado do Rio de Janeiro: relatos das mulheres encarceradas [dissertação]. Rio de Janeiro (RJ): Universidade Federal Fluminense, Programa de Pós-Graduação na Atenção em Saúde MaternoInfantil; 2015.

24. Dumont DM, Brockmann B, Dickman S, Alexander N, Rich JD. Public health and the epidemic of incarceration. Annu Rev Public Health [Internet]. 2012 Apr [cited 2015 Jun 10]; 33:325-39. Available from: http:/ / www.ncbi.nlm.nih.gov/pmc/articles/ PMC3329888/pdf/nihms369306.pdf

25. Borges PCC (Organizador). Sistema penal e gênero: tópicos para a emancipação feminina. São Paulo (SP): Cultura Acadêmica; 2011.

26. Priori C. A construção social da identidade de gênero e as mulheres na prisão. Rev NUPEM [Internet]. 2012 jan/jul [cited 2015 Jun 10]; 3(4):191-0. Available from: http://www.fecilcam.br/revista/index.php/ nupem/article/viewFile/89/64
Correspondence: Diego Pereira Rodrigues

Rua Desembargador Leopoldo Muylaert, 307

24350-450 Piratininga, Niterói, RJ, Brazil

E-mail: diego.pereira.rodrigues@gmail.com
Received: November 27, 2015 Approved: June 30, 2016 